Acta Theriologica 36 (3-4), 307 - 313,1991.

PL ISSN 0001-7051

B1SONIANA 105

\title{
Food eaten by the free-living European bison in Białowieża Forest
}

\author{
Zofia GĘBCZYŃSKA, Marek GĘBCZYŃSKI and Ewa MARTYNOWICZ
}

\begin{abstract}
Gębczyńska Z., Gębczyński M. and Martynowicz E. 1991. Food eaten by the free-living European bison in Bialowieża Forest. Acta theriol. 36: 307 - 313.

Rumen contents of the European bison $(n=67)$ living free in herds within Bialowieża Forest have been estimated. In winters of continuous snow cover, when bison have access to hay offered in feeding racks, their basic food consisted of grasses, sedges and herbs $(90.4 \%$ per cent of the rumen capacity), with trees and shrubs as supplementary food $(9.5 \%$ of the rumen capacity). In spring the proportions of these two groups of plants are 88.2 and $11.2 \%$, in summer 86.3 and $13.0 \%$, in autumn 93.2 and $6.7 \%$, respectively. Mosses, horsetails, ferns and fungi combined account for 0.1 to $0.7 \%$ of the rumen capacity, depending on the season.
\end{abstract}

Mammal Research Institute, Polish Academy of Sciences, 17-230 Bialowieża, Poland and Institute of Biology, Warsaw University, Branch in Bialystok, ul. Świerkowa 20B, 15-950 Białystok, Poland (on which reprints requests should be directed)

Key words: European bison, natural food, comparison of methods

\section{Introduction}

The European bison, Bison bonasus (Linnaeus, 1758) has little known food preferences. Only in a few places in the world do European bison live outside enclosures and have a free choice of food. Białowieża Forest is such a place, although additional food is made available to animals during winter. The reasons for this winter supply of hay have never been clearly identified, but it is known to have started as early as in the 19th century. One unquestionable reason was, that a large number of the European bison, red deer and moose were kept for hunting purposes, so their nutritional needs had to be secured by man (Wróblewski 1927). This tradition of hay supplies has been kept up to the present day. During snowless winters this fodder is not used (Z. Krasiński, personal inf.), a fact which suggests that it is not an indispensable condition for the winter survival.

Studies of the bisons' diet have been carried out so far by taking account of foraging traces (Koroćkina 1969a, b; Borowski and Kossak 1972) or by direct observation of their feeding behaviour in the field (Caboń-Raczyńska et al. 1987). Food preferences were also determined by means of cafeteria tests (Gębczyńska and Krasińska 1972). Prior to these studies information on the food of this mammal was collected from foresters and farmers (cf. Wróblewski 1927, Borowski et al. 1967). Up to now, however, the bison's diet was not asscsed by analysing of the rumen contents, a method which gives direct, quantitative and qualitative estimation of the food intake, despite some limitations (Bergerud and Russell 1964, Gaare et al. 1978). 
The aim of this study was to find, which species of plants were eaten and in what amoints, by the free-living European bison within Białowieża Forest. A comparison was then nade between this data and results obtained in the same area from two other methods: (1) diet assessed by the traces of foraging (Koroćkina 1969a, b, 1972; Borowski and Kossak 172) and (2) the study of feeding behaviour (Caboń-Raczyńska et al. 1987). It allowed not only to improve the knowledge about trophic relationships in the European bison but also to compare the validity of the basic methods used in assessing the diet of wild species of ruminants.

\section{Material and methods}

One-litre samples of rumen contents, fixed with $4 \%$ formalin, were collected in the field, after an incsion of the rumen wall and proper, thorough mixing of its contents. The samples were taken from anmals intentionally culled or killed in accidents. No samples were taken from animals found dead from natural caises. Data was obtained in this way from 44 individuals in winter, 10 in spring, 4 in summer and 9 in autumn. The analysis began by rinsing the samples underrunning water, on a sieve with a $2 \mathbf{m m}$ mesh. The filtrate contained small particles of food and mineral components, mainly sand. The filtrate, after passing through filter )aper and after drying, was weighed, however any identification of species or genera from these contents wa; not possible. Attempts to estimate the specific composition of this fraction indicated, that about $90 \%$ of the fra:tion were herbs and grasses, and the remaining $10 \%$ were leaves and ground twigs. To adjust the data on the food intake, the mass of the tree food was increased by 1/10 of the unidentified fraction, and the mass of the grasses, sedges and herbs by $\mathbf{9 / 1 0}$ of the undetermined fraction. It should be mentioned that although in the Eurcpean bison $\mathbf{1 9 . 5 \%}$ of the rumen contents could not be identified, in other species, for example the caribou (Berjerud and Russell 1964), roe deer and red deer (Gębczyńska 1980) as much as $77 \%$, 58\%, and $45 \%$ respectively, were left undetermined. This comparatively small indeterminable amount in the European bison make: this method of diet assessment more accurate than in the caribou, roe and red deer.

Part of the rumen contents left on the sieve were identified under a dissection microscope. It allowed identification accurate to the level of species or genus. The grasses were much more difficult to identify, though they could be easily distinguished as a systematic group. Therefore they were treated together and idenified only as the family Gramineae.

\section{Study area}

Białowieża Forest is a densely forested area of mixed woods covering a total of $1100 \mathrm{~km}^{2}$. The flcra of this territory consists of 953 species of flowering plants, 37 species of pteridophytes, 254 species of bryoplytes, 54 species of liverworts, about 200 species of lichens and over 2000 species of fungi (Faliński 1986). A de ailed description of the biotopes is given by Borowski and Kossak (1972) and by Krasińska et al. 1987. Generally it can be said that the European bison prefer to live in the Pino-Carpinetiun mixed forests and mixed coniferous woods which cover 47 and 26 per cent of the Forest area, respectively.

The way of gathering in herds, moving around, and the circadian rhythms all influence the utilization of food resources; all these parameters referring to the European bison living in Bialowieża Forest have been well-acknowledged (Krasiński 1978, Krasińska et al. 1987, Caboń-Raczyńska et al. 1987).

\section{Results and discussion}

The analysis of the rumen contents in the European bison living in Białowieża Forest shows that they eat over 90 species of plants, however this number does not take into account individual species of grasses which were not identified. A longer list of plants in the diet was 
made on the basis of the foraging trace analysis and, after Borowski and Kossak (1972), it included 137 species, while after Koroćkina (1969a, b, 1972) - as many as 376 species.

Such large differences in the number of species recorded, i.e. eaten by the bison, may perhaps be explained by the level of accuracy in registering the foraging traces (data after Koroćkina 1969a, b, 1972 versus Borowski and Kossak 1972). On the other hand, in identifying the specific composition of the rumen content, single plants eaten may escape observation and, besides, some of them are not identifiable. If, however, we compare the list of species ( $\mathrm{n}=$ 137) set by Borowski and Kossak (1972), and part of the list accepted by Koroćkina (1969a, $1972)$ as a basic composition $(n=130$, where 45 were the species of trees and shrubs, plus 85 species of grasses and herbs), with our list $(n=93$ species completed with 18 species of grasses after Koroćkina 1972) then all these lists range between 111 and 137 species of plants included in the diet of the bison in Białowieża Forest. Thus, it can be accepted that both methods, to some extent give a similar basic list of the plant species included in the diet.

The morphology of the alimentary tract in the European bison allows us to include it among animals feeding on grass and fibrous fodder (Hofmann 1978), taken in large amounts and with little selectivity. Nevertheless, the bison prefer certain types of food, as well as specific species within these types. This is strongly supported by the fact, that in experimental conditions trees are conspicuously preferred (Gębczyńska and Krasińska 1972). Other evidence of tree food preference is provided by our data on food in winter, where, in spite of grazing in the vicinity of the feeding racks stacked with an overabundance of hay, the bison still ate the twigs and bark from 13 species of trees and 4 species of shrubs. In this period, preferred species were: Picea excelsa, Belula pubescens, Carpinus betulus, Quercus robur (Table 1). From spring to autumn the bison chose Picea excelsa, Pinus silvestris, Quercus robur, Betula pubescens, Carpinus betulus, Populus tremula (Table 1). In this period similar preferences among tree species were recorded by the foraging trace method (Koroćkina 1969a, Borowski and Kossak 1972). Also the cafeteria test showed that Quercur robur, Fraxinus excelsior, Acer platanoides, Salix caprea, Ulmus campestris, Malus silvestris were willingly eaten by the European bison (Gębczyńska and Krasińska 1972).

As regards grasses, sedges and herbaceous plants, assessment of the diet composition clearly depends on the method used. Only several species like: Aegopodium podagraria, Urtica dioica, Ranunculus lanuginosus, give estimates consistent with the method of the rumen content analysis and the method of foraging trace observations (our data versus Borowski and Kossak 1972). The assessment of the rumen contents shows that 50 species of plants occur over $10 \%$ and 22 species of plants over $20 \%$ within the diet components (Table 1). Koroćkina (1972) calculated that 85 species of grasses, sedges and herbs were included in the basic diet, with 18 species belonging to the family of Gramineae, 15 to Compositeae, 20 to Leguminoseae and the remaining species belonging to other families.

The quantitative proportion of individual food types in the rumen contents is surprisingly stable, though from spring to autumn the bison acquire their food in a natural way, while in winter they mainly utilize the hay from the feeding racks (Table 2). Despite this, grasses and sedges contribute from $65.5 \%$ (in spring) to $72.4 \%$ (in winter) of the rumen contents. Most herbaceous plants were found in autumn $(6.7 \%)$ and least in winter $(0.9 \%)$. Surprisingly the presence of trees in the diet was uniform throughout winter, spring and summer (from 7.4 to 
Table 1. Frequency of occurrence (in percentage) of trees, bushes, and herbaceous plants in stomach contents of the European bison from the Bialowieża free-living herd.

\begin{tabular}{ccc}
\hline Species & $\begin{array}{c}\text { Spring - Autumn } \\
(\mathrm{n}=23)\end{array}$ & $\begin{array}{c}\text { Winter } \\
(\mathrm{n}=44)\end{array}$ \\
\hline 1 & 2 & 3 \\
\hline
\end{tabular}

Trees

Picea excelsa (Lam.) Lk.

Carpinus betulus $\mathbf{L}$.

Pimis silvestris $\mathbf{L}$.

Quere us robur $\mathrm{L}$.

Betula pubescens Ehrh.

Populus trémula L.

Tilia cordata Mill.

Alnus glutinosa (L.) Gaertn.

Fraxinus excelsior $\mathrm{L}$.

Ulmus sp.

Salix sp.

Acer pseudoplatanus L.

Acer platanoides L.

$\begin{array}{rr}82.6 & 54.5 \\ 69.5 & 43.2 \\ 56.5 & 18.2 \\ 65.2 & 43.2 \\ 73.9 & 54.5 \\ 43.5 & 18.0 \\ 34.8 & 15.9 \\ 21.1 & 11.3 \\ 20.0 & 0.0 \\ 14.3 & 0.0 \\ 0.0 & 4.6 \\ 11.1 & 0.0 \\ 30.8 & 4.5\end{array}$

Bushes

Corylus avellana $\mathrm{L}$.

Vaccinium myrtillus L.

9.1

Calluna vulgaris (L.) Salisb.

30.0

2.3

Evonymus verrucosa Scop.

10.5

13.2

Vaccinium vitis-idaea $\mathrm{L}$.

Vaccinium uliginosum $\mathrm{L}$.

0.0

9.0

15.4

15.9

61.5

16.8

Frangula alnus Mill.

22.2

6.0

Viburnum opulus L.

Sorbus aucuparia $\mathbf{L}$.

0.0 2.2

$15.4 \quad 0.0$

Ledum palustre $\mathrm{L}$.

Herbaceous plants

Oxalis aceto sella $\mathbf{L}$.

Stellaria holostea L.

Ajuga reptans $\mathrm{L}$.

Urtica dioica $\mathrm{L}$.

Geum urbanum $\mathrm{L}$.

Aegopodium podagraria $\mathrm{L}$.

Galeobdolon luteum Huds.

Stachys silvático $\mathbf{L}$.

Cardamine amara $\mathrm{L}$.

Geranium Robertianum L.

Anemone nemorosa $\mathrm{L}$.

15.8

Solanum tuberosum $\mathrm{L}$.

Rumex sp.

Hepatica nobilis Gersault

Mycelis muralis (L.)

Paris quadrifolia $\mathrm{L}$.

Asarum europaeum $\mathrm{L}$. 
Table 2 continued

\begin{tabular}{|c|c|c|}
\hline 1 & 2 & 3 \\
\hline Stellaria nemoriim $\mathbf{L}$. & 10.0 & $\mathbf{0 . 0}$ \\
\hline Stellaria media (L.) Vill. & 21.7 & 2.3 \\
\hline Ficaria verna Huds. & 10.0 & $\mathbf{0 . 0}$ \\
\hline Veronica chamaedrys $\mathrm{L}$. & 10.5 & $\mathbf{0 . 0}$ \\
\hline Vicia sp. & 0.0 & 4.6 \\
\hline Plantago sp. & 44.4 & 6.8 \\
\hline Lathyrus pratensis $\mathrm{L}$. & 15.4 & 9.1 \\
\hline Ranunculus repens $\mathrm{L}$. & 15.4 & 15.9 \\
\hline Artemisia vulgaris L. & 0.0 & 6.8 \\
\hline Filipéndula ulmaria (L.) Maxim. & 38.4 & 15.9 \\
\hline Actaea spicata $\mathrm{L}$. & 11.1 & 4.5 \\
\hline Sonchus arvensis $\mathrm{L}$. & 0.0 & 2.3 \\
\hline Geum rivale $\mathrm{L}$. & 15.4 & 4.6 \\
\hline Lathraea squamaria $\mathrm{L}$. & 11.1 & $\mathbf{0 . 0}$ \\
\hline Chenopodium sp. & 11.1 & 0.0 \\
\hline Leontodon autumnalis $\mathrm{L}$. & 11.1 & 2.3 \\
\hline Potentilla anserina $\mathrm{L}$. & 11.1 & $\mathbf{0 . 0}$ \\
\hline Circaea lutetiana $\mathbf{L}$. & 11.1 & $\mathbf{0 . 0}$ \\
\hline Valeriana officinalis $\mathbf{L}$. & 11.1 & 0.0 \\
\hline Primula officinalis (L.) Hill. & $\mathbf{0 . 0}$ & 2.3 \\
\hline Chrysosplenium allernifolium $\mathrm{L}$. & 0.0 & 2.3 \\
\hline Capsella bursa-pastoris (L.) Med. & 22.2 & 0.0 \\
\hline Dentaria bulbifera $\mathrm{L}$. & 22.2 & 0.0 \\
\hline Genista tincloria $\mathbf{L}$. & 11.1 & 0.0 \\
\hline Piróla sp. & 25.0 & 0.0 \\
\hline Epilobium alsinifolium Vill. & 11.1 & 0.0 \\
\hline Galium sp. & 11.1 & $\mathbf{0 . 0}$ \\
\hline Lotus corniculatus $\mathbf{L}$. & 11.1 & $\mathbf{0 . 0}$ \\
\hline Majanthemum bifolium (L.) F. W.Schmidt & 25.0 & $\mathbf{0 . 0}$ \\
\hline Fragaria vesca $\mathrm{L}$. & 25.0 & 0.0 \\
\hline Brassica sp. & 11.1 & 0.0 \\
\hline Compositae & 11.1 & 0.0 \\
\hline Leguminoseae & 11.1 & 11.3 \\
\hline Beta vulgaris $\mathrm{L}$. & 25.0 & 31.8 \\
\hline
\end{tabular}

Table 2. Frequency of biomass of the different food groups in the stomach of the European bison.

\begin{tabular}{lcccc}
\hline Food group & $\begin{array}{c}\text { Spring } \\
\text { (April - May) } \\
\mathrm{n}=\mathbf{1 0}\end{array}$ & $\begin{array}{c}\text { Summer } \\
\text { (June - Aug.) } \\
\mathrm{n}=\mathbf{4}\end{array}$ & $\begin{array}{c}\text { Autumn } \\
\text { (Sept. - Oct.) } \\
\mathrm{n}=\mathbf{9}\end{array}$ & $\begin{array}{c}\text { Winter } \\
\text { (Nov. - March) } \\
\mathbf{n}=\mathbf{4 4}\end{array}$ \\
\hline Trees & $\mathbf{8 . 8}$ & 9.8 & 4.3 & 7.4 \\
Bushes & 0.1 & 1.4 & 0.6 & 0.2 \\
Grasses and sedges & 65.5 & 68.6 & 69.9 & 72.4 \\
Herbaceous plants & 1.5 & 1.7 & 6.7 & 0.9 \\
Mosses & 0.2 & 0.5 & 0.0 & 0.0 \\
Pteridophytes & 0.4 & 0.2 & 0.0 & 0.1 \\
Fungi & 0.0 & 0.0 & 0.1 & 0.0 \\
Unidentified parts & 23.5 & 17.8 & 18.0 & 19.0 \\
\hline
\end{tabular}


Table 3. Estimations of occurrence (\%) of trees and bushes (A); grasses, sedges and herbs (B) in thi bison diet, according to the different methods.

\begin{tabular}{rllll}
\hline A & B & \multicolumn{1}{c}{ Season } & \multicolumn{1}{c}{ Method } & \multicolumn{1}{c}{ Authority } \\
\hline 33 & 67 & Spring - autumn & Feeding traces in the forest & Borowski and Kossak 19"2 \\
39 & 61 & Winter and summer & Cafeteria test in the enclosure & Gębczyńska and Krasińska 1972 \\
$4.8^{1}$ & 95.2 & Spring - autumn & Direct observations in the forest & Caboń-Raczyńska et al. 1987 \\
$9.5^{2}$ & 90.4 & Winter & Stomach contents analysis & This study \\
11.2 & 88.2 & Spring & As above & As above \\
13.0 & 86.3 & Summer & As above & As above \\
6.7 & 93.2 & Autumn & As above & As above \\
\hline
\end{tabular}

'in April bison may bark up to $\mathbf{2 0 . 7 \%}$ of the feeding time and in June and July they may browse up to $\mathbf{1 1 . 8 \%}$ of the feeding time.

${ }^{2}$ To adjust data on food intake calculated by stomach contents analysis the mass of tree food was increased by $10 \%$ of the unidentified fraction, and the mass of grasses, sedges and herbs was increased by $90 \%$ respectively (for details see in the text).

9.8\%) and only in autumn was it lower (4.3\%). Mosses, ferns, horsetails and fungi were always found in amounts below one per cent of the total rumen contents (Table 2). The adjustments used to incorporate the unidentifiable food in the rumen contents, correspondingly increased the proportion of trees and shrubs as well as grasses, sedges and herbs (compare Table 3).

The presence of tree food in the diet of other ruminants in Białowieża Forest ranges considerably: in roe deer it comprises $12 \%$ in summer and $23 \%$ in winter (Gębczyńska 1980). According to Kossak (1983) the roe deer covers its requirements of tree food from spring to autumn in variable amounts (from less than $10 \%$ to $60 \%$ ); in the snowless period of winter about $15 \%$ and nearly $100 \%$ during permanent snow cover. On the other hand, in the red deer this proportion comprises $60 \%$ in autumn and winter (Gębczyńska 1980). The European bison have additional hay provided in winter and this fact influences its diet composition during this season, the extent to which is not quite known.

During snowless winters the bison in Białowieża Forest did not utilize the food provided on racks (Z. Krasiński, personal inf.). However, so far it has not been possible to obtain samples of the rumen from such individuals. Only if this was possible could it be determined whether the proportion of the tree food taken by the European bison depends upon the season or not. There was a striking difference in the proportion of trees, shrubs, grasses and herbs in the bisons' diet from spring to autumn, when the various methods used, were compared (Table 3). The results of food obtained using the method of foraging traces, tends to overestimate the percentage of tree food in the diet of the European bison. A similar fact was found in studies on roc deer and red deer (Gębczyńska 1980). On the other hand direct observations of the bisons' feeding behaviour in the forest showed that most of their time is spent grazing as much as $95.2 \%$ of time, while barking and browsing constitutes only $4.8 \%$ (Caboń-Raczyńska et al. 1987). As the contents of the rumen indicates that the food taken from trees and shrubs contributes about $10 \%$ of the diet, it is likely that this food is digested quite slow or, even more likely, that the actual bites taken are of a substantial size. Accepting such an assumption allows us to say that direct observations of the bison feeding habits underestimates the amount 
of tree food in their diet. If we accept, according to the rumen contents, the quantitative estimates of the percentages of food groups as the nearest to the actual figure; it can be stated that the European bison feeds principally on grasses, sedges and herbs (about $90 \%$ of the diet) and supplements it with the tree food (about $10 \%$ of the diet). These figures remain in similar proportions also during the winter period, when additional feeding of the European bison in Białowieża Forest is applied.

Acknowledgement: We would like to express our thanks to Mr. Ewen McNeish for his thorough linguistic corrections.

\section{References}

Bergerud A. T. and Russell L. 1964. Evaluation of rumen food analysis for Newfoundland caribou. J. Wildl. Manage. 28: 809 - 814.

Borowski S. and Kossak S. 1972. The natural food preferences of the European bison in seasons free of snow cover. Acta theriol. 17: 151 - 169.

Borowski S., Krasiński Z. and Milkowski L. 1967. Food and role of the European bison in forest ecosystems. Acta theriol. 19: 283 - 289.

Caboń-Raczyńska K., Krasińska M., Krasiński Z. A. and Wójcik J. M. 1987. Rhytm of daily activity and behavior of European bison in the Białowieża forest in the period without snow cover. Acta theriol. 32: 335 - 372.

Faliński J. B. 1986. Vegetation dynamics in temperate lowland primeval forest. Junk Publishers: 1 - 537.

Gaare E., Sorensen A. and White R. G. 1978. Are rumen samples representative of the diet? Oikos 29: 221 237.

Gębczyńska Z. 1980. Food of the roe deer and red deer in the Bialowieża Primeval Forest. Acta theriol. 25: 487 - 500.

Gębczyńska Z. and Krasińska M. 1972. Food preferences and requirements of the European bison. Acta theriol. 17: $105-117$.

Hofmann R. R. 1978. Die Stellung der Europäischen Wildwiederkauer in System der Äsungstypen. [In: Wildbiologische Informationen für den Jäger. R. R. Hofmann, ed.]. Jagd + Hege - Verlag, St. Gallen: 1 - 142.

Koročkina L. N. 1969a. Drevesnaja rastitelnost' v pitanii zubrov Belov̌ezskoj Pǔści. Belovežskaja Pǔsia, Issledovanija 3: 120 - 126.

${ }^{`}$ Korockina L. N. 1969b. Vidovoj sostav lesnoj travianistoj rastitelnosti v pitanii zubrov Beloveźskoj Pusći. Belovezškaja PuScă, Issledovanija 3: 204 - 221.

KoroCkina L. N. 1972. Travjanistaja rastitelnost' v pitanii zubrov Belovězskoj Pǔsći. Belovežskaja Pušća, Issledovanija 6: 110 - 124.

Kossak S. 1983. Trophic relations of roe deer in a fresh deciduous forest. Acta theriol. 28: 83 - 127.

Krasińska M., Caboń-Raczyńska K. and Krasiński Z. 1987. Strategy of habitat utilization by European bison in the Białowieża Forest. Acta theriol. 31: 147 - 203.

Krasiński Z. A. 1978. Dynamics and structure of the European bison population in the Bialowieża Primeval Forest. Acta theriol. 23: 3 - 48.

Wróblewski K. 1927. Żubr Puszczy Białowieskiej. Monografia. Wyd. Pol. Poznań: 1 - 232.

Received 12 April 1991, accepted 18 October 1991. 